\title{
Transmission disequilibrium test of stromelysin-1 gene variation in relation to Crohn's disease
}

\author{
S L F Pender, P J P Croucher, S Mascheretti, J D Prothero, S A Fisher, T T MacDonald, S Schreiber, \\ Shu Ye
}

J Med Genet 2004;41:e1 12 (http://www.jmedgenet.com/cgi/content/full/41/9/e112). doi: 10.1136/jmg.2004.023572

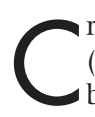
rohn's disease (MIM 266600) and ulcerative colitis (MIM 191390) are the major forms of inflammatory bowel disease (MIM 601458), the prevalence of Crohn's disease being more than $1 / 1000$ in the Western countries. Inflammatory bowel disease is characterised by chronic relapsing intestinal inflammation, and its pathogenesis probably involves microbial, immunological, environmental, and genetic factors. ${ }^{2}{ }^{3}$ Recent genetic association studies have shown that sequence variations in the Caspase Activating Recruitment Domain (CARD15) gene (MIM605956, formerly named NOD2) on chromosome $16 \mathrm{q}$ are a strong genetic factor for Crohn's disease but not for ulcerative colitis. ${ }^{4-6}$ CARD15 represents the first major Crohn's disease susceptibility gene identified, and its identification might facilitate the uncovering of other genetic factors for the disease.

The matrix metalloproteinases (MMP) are a group of matrix degrading enzymes that play an important role in the pathogenesis of various inflammatory diseases including osteoarthritis, rheumatoid arthritis, atherosclerosis, cancers, and inflammatory bowel disease. ${ }^{7}$ We have shown that, of four MMPs studied (interstitial collagenase, gelatinase A and $\mathrm{B}$, and stromelysin-1), stromelysin- 1 in particular is directly involved in mucosal destruction following $\mathrm{T}$ cell activation in the human fetal gut. ${ }^{8}$ Furthermore, patients with Crohn's disease have increased expression of stromelysin-1 in the mucosa at both the mRNA and protein levels. ${ }^{9}$ Microarray techniques have demonstrated that stromelysin-1 expression is increased 8.7-fold in the mucosa of patients with Crohn's disease compared with healthy controls (Pender SLF, unpublished data), and have also shown that stromelysin-1 expression is 8.2-fold higher relative to controls in PWM stimulated human fetal gut explant culture. ${ }^{10}$ Thus, although the stromelysin-1 gene on chromosome 1lq23 is not located within the particular chromosomal regions (19p13, 16q12, 16p, 14q11-q12, 12pl3.2-q24.1, 6p, 5q31, and 1p36) that have been shown to be in linkage with inflammatory bowel disease (MIN 266600), it is a strong functional candidate gene that might have an influence on this multifactorial disorder.

We have previously identified a functional polymorphism in the promoter of the stromelysin-1 gene. ${ }^{11}$ The polymorphism arises from insertion or deletion of an adenosine within a cluster of adenosines located at position -1612 and upwards, relative to the transcriptional start site of the gene, with one allele having a cluster of five adenosines (5A) and the other allele having six adenosines (6A). In vitro assays have shown that the $5 \mathrm{~A}$ allele has a higher promoter activity than the $6 \mathrm{~A}$ allele, with differential binding of a nuclear protein to the two allelic promoters. ${ }^{12}$

Given that increased stromelysin-1 expression plays an important role in the development of Crohn's disease and that the $5 \mathrm{~A} / 6 \mathrm{~A}$ polymorphism has an allele specific effect on stromelysin-1 expression, individuals carrying the 5A allele might have increased susceptibility to Crohn's disease. We tested this hypothesis in the present study.

\section{Key points}

- Stromelysin-1, an extracellular matrix degrading enzyme, is involved in tissue destruction in Crohn's disease.

- To investigate whether the stromelysin-1 gene 5A/6A polymorphism was associated with susceptibility to Crohn's disease, this polymorphism was analysed in 468 German sporadic inflammatory bowel disease trios and 270 British and German multiplex inflammatory bowel disease families using the transmission disequilibrium test.

- There was overtransmission of the $5 \mathrm{~A}$ allele to affected offspring in the German sporadic Crohn's disease trios $(p=0.0012)$.

- There was an interaction between the stromelysin-1 gene $5 \mathrm{~A} / 6 \mathrm{~A}$ polymorphism and the CARD15 gene, a well established gene for Crohn's disease, such that overtransmission of the 5A allele to affected offspring in the German sporadic Crohn's disease trios was significant in CARD15 variant carriers $(p=0.0054)$ but not in non-carriers.

- In the CARD15 variant carriers, overtransmission of the 5A allele was associated with stenosis $(p=0.0027)$, fistulising disease $(p=0.0007)$, previous surgical resection $(p=0.0023)$, and disease of the ileum $(p=0.0001)$ and right colon $(p=0.0115)$.

- The stromelysin-1 gene $5 \mathrm{~A}$ allele appears to represent a genetic factor for Crohn's disease.

\section{METHODS}

\section{Subjects}

The stromelysin- 1 gene $5 \mathrm{~A} / 6 \mathrm{~A}$ polymorphism was analysed in a collection of trios from Germany, each consisting of one patient with inflammatory bowel disease and their two unaffected parents (table 1). In addition, the polymorphism was analysed in a cohort of German families and a cohort of British families, each with multiple cases of inflammatory bowel disease (table 1). These samples were recruited by an international group of inflammatory bowel disease investigators at the Charité University Hospital (Berlin, Germany), the Christian-Albrechts-Universtität Hospital (Kiel, Germany), St Mark's Hospital (London, UK), Guy's Hospital (London, UK), King's College Hospital (London,

Abbreviations: CARD, caspase activating recruitment domain; MMP, matrix metalloproteinase; PWM, pokeweed mitogen; TDT, transmission disequilibrium test 
UK), and several additional German centres. The characteristics of the subjects have been described previously. ${ }^{5}{ }^{13-16}$

Informed, written consent was obtained from all study participants. Recruitment protocols were approved by ethics committees at the participating centres before the study began. The diagnosis of inflammatory bowel disease and the classification into Crohn's disease and ulcerative colitis were determined by standard diagnostic criteria. ${ }^{17}{ }^{18}$ Clinical, radiological, and endoscopic examinations (type of lesions, distribution) were required for unequivocal confirmation of the diagnosis of either ulcerative colitis or Crohn's disease. Histological findings also had to be confirmative or compatible with this diagnosis. In cases of uncertainty, the diagnosis of indeterminate colitis was assigned and the patient excluded from the study.

\section{Genotyping}

Genomic DNA was prepared from $10 \mathrm{ml}$ of fresh or frozen peripheral venous blood using the Puregene system (Gentra Systems, Minneapolis, Minnesota, USA). Individual DNA samples were arrayed in 96-well microtitre plates. The stromelysin-1 gene 5A/6A polymorphism was genotyped by TaqMan $5^{\prime}$-nuclease assay using the following primers and probes (designed on the reverse strand): forward primer $5^{\prime}$ GCCACCACTCTGTTCTCCTTGTC 3', reverse primer 5' CACG GCACCTGGCCTAAAGA 3'; first probe (6A) 5' CAAGACATGG TTTTTTCCCCCCATCA $3^{\prime}$, second probe (5A) 5' CAAGACAT GGTTTTTCCCCCCATCA 3'. Primers and probes were designed with the Primer Express program (Aplera, Foster City, California, USA) and synthesised by Eurogentec (Liège, Belgium). The amplification reaction, done in a Biometra Tl thermocycler (Biometra, Göttingen, Germany), involved two pre-polymerase chain reaction (PCR) steps of two minutes at $50^{\circ} \mathrm{C}$ and 10 minutes at $95^{\circ} \mathrm{C}$, followed by 50 cycles including a denaturation step at $95^{\circ} \mathrm{C}$ for 15 seconds and an annealing and extension step at $64^{\circ} \mathrm{C}$ for one minute, in a total volume of $5 \mu \mathrm{l}$ with $100 \mathrm{nM}$ of probes and $300 \mathrm{nM}$ of primers.

\section{Statistical analysis}

An integrated database ${ }^{19}$ was used to manage the genotyping data. Transmission disequilibrium tests (TDT) of the 5A/6A polymorphism in relation to inflammatory bowel disease, Crohn's disease, and ulcerative colitis in the German trios and in the German and British families were undertaken using the TRANSMIT program ${ }^{20}{ }^{21}$ with the robust variance estimator option. TDT of the $5 \mathrm{~A} / 6 \mathrm{~A}$ polymorphism in relation to various phenotypes of Crohn's disease in the German trios was also carried out using the TRANSMIT program. Significances were verified using 10000 bootstrap replicates.

Possible interaction between the stromelysin gene and the CARD15 gene was examined by stratifying the patients according to their CARD15 genotype. Individuals carrying one or more copies of the R702W, G908R, or 1007insC mutations ${ }^{4-6}$ were classified as CARD15+, and individuals not carrying these mutations as CARD15-.

\section{RESULTS}

Analyses in German sporadic inflammatory bowel disease trios

Transmission disequilibrium tests in the German sporadic inflammatory bowel disease trios showed a highly significant association between Crohn's disease and overtransmission of the $5 \mathrm{~A}$ allele $(\mathrm{p}=0.0012$, table 2$)$. No significant association between ulcerative colitis and the stromelysin-l gene was detected.

There was an interaction between stromelysin-l and CARD15 genes, such that the association of the stromelysin1 gene 5A allele with Crohn's disease was apparent only in individuals carrying one or more mutations in the CARD15 gene $(\mathrm{p}=0.0054$, table 3$)$. In CARD15 mutation carriers, overtransmission of the $5 \mathrm{~A}$ allele was associated with various Crohn's disease traits, including stenosis $(p=0.0027)$, fistulising disease $(p=0.0007)$, previous surgical resection $(\mathrm{p}=0.0023)$, and disease of the ileum $(\mathrm{p}=0.0001)$ and right colon $(\mathrm{p}=0.0115$; NS after correcting for multiple testing) (table 3 ).

There was no evidence of interaction between the stromelysin gene and smoking in relation to the development of Crohn's disease. In individuals carrying one or more mutations in the CARD15 gene, there was significant overtransmission of the $5 \mathrm{~A}$ allele in the trios, regardless whether the offspring had smoked (observed/expected 5A allele transmission ratio, 69/59.65; $p=0.0147$ ) or had never smoked (observed/expected 5A allele transmission ratio, 76/ 65.87; $\mathrm{p}=0.0239)$.

In non-carriers of the CARD15 gene mutations, there was no significant overtransmission of the $5 \mathrm{~A}$ allele in the trios, regardless of whether the offspring had smoked or not $(\mathrm{p}=0.6231, \mathrm{p}=0.6379$, respectively).

\section{Analyses in the multiplex inflammatory bowel disease families}

No significant association between the stromelysin-1 5A/6A polymorphism and Crohn's disease or ulcerative colitis was detected in the German and British families with familial inflammatory bowel disease (table 2), and this was not affected by stratification for CARD15 genotype.

\section{DISCUSSION}

In this study we showed an association of Crohn's disease susceptibility with the stromelysin-1 gene $5 \mathrm{~A} / 6 \mathrm{~A}$ polymorphism in a cohort of German sporadic Crohn's disease trios. As increased stromelysin-1 gene expression plays an important

Table 1 Subjects genotyped for the stromelysin-1 gene 5A/6A polymorphism

\begin{tabular}{|c|c|c|c|c|}
\hline & Disease & $\begin{array}{l}\text { Number of } \\
\text { trios or families }\end{array}$ & $\begin{array}{l}\text { Number of affected } \\
\text { offspring per family }\end{array}$ & $\begin{array}{l}\text { Number of trios or families where } \\
\text { both parents were genotyped }\end{array}$ \\
\hline \multirow{2}{*}{$\begin{array}{l}\text { German sporadic } \\
\text { IBD trios }\end{array}$} & $C D$ & 320 & 1 & 318 (ie, in $99.4 \%$ of the collection) \\
\hline & UC & 148 & 1 & 147 (ie, in $99.3 \%$ of the collection) \\
\hline \multirow{2}{*}{$\begin{array}{l}\text { German multiplex } \\
\text { IBD families }\end{array}$} & $C D$ & 135 & 1 in 47 families, 2 in 82 & 115 (ie, in $85.2 \%$ of the collection) \\
\hline & UC & 83 & $\begin{array}{l}1 \text { in } 44 \text { families, } 2 \text { in } 39 \\
\text { families }\end{array}$ & 70 (ie, in $84.3 \%$ of the collection) \\
\hline \multirow{2}{*}{$\begin{array}{l}\text { British multiplex } \\
\text { IBD families }\end{array}$} & $C D$ & 91 & 1 in 40 families, 2 in 44 & 78 (ie, in $85.7 \%$ of the collection) \\
\hline & UC & 49 & $\begin{array}{l}1 \text { in } 28 \text { families, } 2 \text { in } 17 \\
\text { families, } 3 \text { in } 4 \text { families }\end{array}$ & 42 (ie, in $85.7 \%$ of the collection) \\
\hline
\end{tabular}


Table 2 Results of transmission disequilibrium test

\begin{tabular}{|c|c|c|c|c|}
\hline & \multicolumn{2}{|c|}{ Crohn's disease } & \multicolumn{2}{|c|}{ Ulcerative colitis } \\
\hline & $\mathrm{O} / \mathrm{E}$ & p Value* & O/E & p Value* \\
\hline German sporadic IBD trios & $279 / 250.63$ & 0.0012 & $129 / 128.98$ & 0.9955 \\
\hline German multiplex IBD families & $252 / 247.51$ & 0.5133 & $124 / 119.91$ & 0.4331 \\
\hline British multiplex IBD families & $151 / 152.69$ & 0.7600 & $62 / 64.46$ & 0.4642 \\
\hline
\end{tabular}

role in the development of Crohn's disease, the association of the stromelysin-l gene 5A allele with increased Crohn's disease susceptibility is likely to reflect increased expression of stromelysin-1 in 5A allele carriers, which would be consistent with results of functional studies showing that the $5 \mathrm{~A}$ allele had a higher transcriptional activity than the $6 \mathrm{~A}$ allele. We also found that there is an interaction between the stromelysin-1 gene and the CARD15 gene in determining Crohn's disease susceptibility. The underlying mechanism for this observation is unclear. One possibility would be that non-genetic factors play a greater role in the non-carriers of the CARD15 gene mutations than in the carriers, making the modest effect of the stromelysin-1 gene less detectable in the non-carriers of the CARD15 gene mutations. The possibility that stromelysin-1 and CARD15 interact at the cellular or molecular level could not be ruled out.

As smoking is an established environmental risk factor for Crohn's disease, and previous studies have shown an interaction between the $5 \mathrm{~A} / 6 \mathrm{~A}$ polymorphism and smoking in relation to the risk of coronary heart disease, ${ }^{22}{ }^{23}$ we explored whether there was an interaction between the $5 \mathrm{~A} /$ 6A polymorphism and smoking in Crohn's disease, but did not find evidence of such an interaction.

The association between the stromelysin-l gene $5 \mathrm{~A} / 6 \mathrm{~A}$ polymorphism and Crohn's disease was not detected in the multiplex families in this study. There are several possible explanations for the presence of an association of Crohn's disease with the stromelysin-1 gene $5 \mathrm{~A} / 6 \mathrm{~A}$ polymorphism in the sporadic Crohn's disease trios, and the absence of such an association in the multiplex families. First, it is possible that the stromelysin-1 gene $5 \mathrm{~A} / 6 \mathrm{~A}$ polymorphism is associated with a subset of Crohn's disease phenotypes that are enriched in the sporadic Crohn's disease trios but underrepresented in the multiplex Crohn's disease families. However, we did not find a significant difference between the trios and the

Table 3 Results of transmission disequilibrium test in German sporadic inflammatory bowel disease trios stratified for CARD15 genotype

\begin{tabular}{llll}
\hline & CARDI5 & O/E & p Value $^{*}$ \\
\hline Crohn's disease & + & $166 / 147.49$ & 0.0054 \\
& - & $170 / 167.04$ & 0.6718 \\
Stenosis & + & $116 / 98.56$ & 0.0027 \\
Fistulae & - & $100 / 100.89$ & 0.871 \\
& + & $103 / 84.60$ & 0.0007 \\
Resection & - & $90 / 90.39$ & 0.942 \\
& + & $106 / 89.39$ & 0.0023 \\
lleal & - & $89 / 87.87$ & 0.8284 \\
& + & $147 / 124.78$ & 0.0001 \\
Right colon & + & $124 / 124.84$ & 0.891 \\
& + & $124 / 109.3$ & 0.0115 \\
Left colon & + & $114 / 114.84$ & 0.8805 \\
& - & $57 / 52.19$ & 0.2165 \\
& - & $113 / 113.56$ & 0.9206 \\
\hline
\end{tabular}

*After 10000 bootstrap replicates.

CARD15 mutation, + indicates carriers of the R702W, G908R, or 1007ins C mutation; - indicates non-carriers.

$\mathrm{O} / \mathrm{E}$, observed/expected $5 \mathrm{~A}$ allele transmission ratio. multiplex families in the frequencies of the phenotypes listed in table 3. Second, as the trios represent sporadic inflammatory bowel disease whereas the multiplex families represent familial disease, it is possible that other not yet identified genes have greater effects on the development of Crohn's disease in the multiplex families than in the sporadic Crohn's disease trios, and thus the modest effect of the stromelysin- 1 gene would be more easily detectable in the latter than in the former. Another possible explanation might be the lack of statistical power in the family samples, as the sample sizes of the German and British multiplex families and the casecontrol set were substantially smaller than those of the trio collection. In addition, in about $15 \%$ of the German and British families only one parent was genotyped, which would further reduce the statistical power in these samples. In comparison, in nearly $100 \%$ of the trios, both parents were genotyped.

In this study, no association between ulcerative colitis and the stromelysin-1 gene $5 \mathrm{~A} / 6 \mathrm{~A}$ polymorphism was detected. Although Crohn's disease and ulcerative colitis are both major forms of inflammatory bowel disease, previous studies have shown that CARD15 gene mutations are associated with Crohn's disease but not with ulcerative colitis, ${ }^{4-6}$ suggesting that they have different pathological mechanisms.

Functional studies have revealed that the $5 \mathrm{~A}$ allele has a higher transcriptional activity than the 6A allele, with preferential binding of a transcription repressor to the latter. $^{12} 2425$ Stromelysin-1 plays an important role in the development of several diseases where the pathogenesis involves inflammation and matrix degradation and remodelling. An association between the $5 \mathrm{~A} / 6 \mathrm{~A}$ polymorphism and phenotypes of coronary heart disease has been shown in various studies, such that carriers of the $5 \mathrm{~A}$ allele have increased risk of myocardial infarction-a clinical event associated with matrix degradation in coronary atherosclerotic plaques-whereas 6A homozygotes have greater atherosclerotic plaque growth, which is associated with matrix accumulation. ${ }^{1126-28}$ Taken together, the functional data and genetic epidemiological observations indicate that genetic variation in the promoter of the stromelysin-1 gene can alter the levels of stromelysin-1 expression, leading to an imbalance between synthesis and degradation of vascular matrix - that is, an imbalance favouring matrix degradation in individuals carrying the $5 \mathrm{~A}$ allele, contrasted by an imbalance favouring matrix accumulation in 6A homozygotes.

In addition to atherosclerosis, several other pathological conditions have been associated with the stromelysin-1 gene 5A/6A polymorphism. For example, a recent study showed that this polymorphism is associated with susceptibility and progression of primary sclerosing cholangitis. ${ }^{29}$ An association between this genetic variation and rheumatoid arthritis has also been reported. ${ }^{30}$ The results of our present study suggest that the stromelysin-1 5A/6A polymorphism might also be related to Crohn's disease. However, the findings of this study need confirmation in an independent study before the stromelysin-1 gene may be considered an established 
genetic risk factor for this disease. In contrast to rare mutations with large functional effects, such as the CARD15 mutations, the $5 \mathrm{~A} / 6 \mathrm{~A}$ polymorphism is a common variant and would probably have only moderate effects on stromelysin- 1 expression and disease susceptibility.

\section{ACKNOWLEDGEMENTS}

We wish to thank our technical staff. We particularly wish to thank Drs Christopher G Mathew (GKT School of Medicine, King's College Hospital, London) for providing CARD15 genotypes; Drs Andrew Macpherson, Steven Bridger (GKT School of Medicine, King's College Hospital, London), John E Lennard-Jones and John Lee (St Mark's Hospital, Harrow, UK) for the British patient collection; and Drs Jochen Hampe, Jochen Grebe, Susanna Nikolaus, and Tanja Kühbacher (CAU Kiel) for their role in patient recruitment. We also thank the cooperating clinical centres, their physicians, the families and patients with IBD, and the German Crohn's and colitis foundation (DCCV e.V) for support and participation. In addition, we would like to thank the following funding bodies for grant support: National Association for Colitis and Crohn's Disease (UK), the Hope Innovation Fund (UK), Wessex Medical Trust (UK), the British Heart Foundation, the Deutsche Forschungsgemeinshaft (For423), a TMR Network Grant of the European Union (ERB4061-PL-97-0389), a Competence Network "Chronisch-entzündliche Darmerkrankungen", the German Human Genome Project (DHGP), and the National Genome Research Network (all funded by the German Federal Department for Research and Education).

\section{Authors' affiliations}

S L F Pender, J D Prothero, T T MacDonald, Infection, Inflammation and Repair Division, University of Southampton, School of Medicine, Southampton, UK

S Ye, Human Genetics Division, University of Southampton, School of Medicine, Southampton

P J P Croucher, S Mascheretti, S Schreiber, Department of General Internal Medicine, Christian-Albrechts-Universtity, Kiel, Germany S A Fisher, Division of Genetics and Development, Guy's, King's and St Thomas' School of Medicine, King's College London, London SEI, UK Conflicts of interest: none declared

S L F Pender and P J P Croucher contributed equally to this paper

Correspondence to: Dr Shu Ye, Human Genetics Division, Duthie Building (808), Southampton General Hospital, Southampton SO16 6YD, UK; shu.ye@soton.ac.uk

\section{REFERENCES}

1 Probert CS, Jayanthi V, Rampton DS, Mayberry JF. Epidemiology of inflammatory bowel disease in different ethnic and religious groups: limitations and aetiological clues. Int J Colorectal Dis 1996;11:25-8.

2 Fiocchi C. Inflammatory bowel disease: etiology and pathogenesis. Gastroenterology 1998;115:182-205.

3 Farrell RJ, Peppercorn MA. Ulcerative colitis. Lancet 2002;359:331-40.

4 Hugot JP, Chamaillard M, Zouali H, Lesage S, Cezard JP, Belaiche J, Almer S, Tysk C, O'Morain CA, Gassull M, Binder V, Finkel Y, Cortot A, Modigliani R, Laurent-Puig P, Gower-Rousseau C, Macry J, Colombel JF, Sahbatou M, Thomas G. Association of NOD2 leucine-rich repeat variants with susceptibility to Crohn's disease. Nature 2001;411:599-603.

5 Hampe J, Cuthbert A, Croucher PJ, Mirza MM, Mascheretti S, Fisher S, Frenzel H, King K, Hasselmeyer A, Macpherson AJ, Bridger S, van Deventer S, Forbes A, Nikolaus S, Lennard-Jones JE, Foelsch UR, Krawczak M, Lewis C, Schreiber S, Mathew CG. Association between insertion mutation in NOD2 gene and Crohn's disease in German and British populations. Lancet 2001;357:1925-8.

6 Ogura Y, Bonen DK, Inohara N, Nicolae DL, Chen FF, Ramos R, Britton H, Moran T, Karaliuskas R, Duerr RH, Achkar JP, Brant SR, Bayless TM, Kirschner BS, Hanauer SB, Nunez G, Cho JH. A frameshift mutation in NOD2 associated with susceptibility to Crohn's disease. Nature 2001;41 1:603-6.

7 Murphy G, Docherty AJ. The matrix metalloproteinases and their inhibitors. Am J Respir Cell Mol Biol 1992;7:120-5.

8 Pender SL, Tickle SP, Docherty AJ, Howie D, Wathen NC, MacDonald TT. A major role for matrix metalloproteinases in T cell injury in the gut. $J$ Immunol 1997; 158:1582-90.
9 Heuschkel RB, MacDonald TT, Monteleone G, Bajaj-Elliott M, Smith JA Pender SL. Imbalance of stromelysin-1 and TIMP-1 in the mucosal lesions of children with inflammatory bowel disease. Gut 2000;47:57-62.

10 Salmela MT, MacDonald TT, Black D, Irvine B, Zhuma T, Saarialho-Kere U, Pender SL. Upregulation of matrix metalloproteinases in a model of T cell mediated tissue injury in the gut: analysis by gene array and in situ hybridisation. Gut 2002;51:540-7.

11 Ye S, Watts GF, Mandalia S, Humphries SE, Henney AM. Preliminary report: genetic variation in the human stromelysin promoter is associated with progression of coronary atherosclerosis. Br Heart J 1995;73:209-15.

12 Ye S, Eriksson P, Hamsten A, Kurkinen M, Humphries SE, Henney AM. Progression of coronary atherosclerosis is associated with a common genetic variant of the human stromelysin-1 promoter which results in reduced gene expression. J Biol Chem 1996;271:13055-60.

13 Curran ME, Lau KF, Hampe J, Schreiber S, Bridger S, Macpherson AJ, Cardon LR, Sakul H, Harris TJ, Stokkers $P$, van Deventer SJ, Mirza M, Raedler A, Kruis W, Meckler U, Theuer D, Herrmann T, Gionchetti P, Lee J, Mathew C, Lennard-Jones J. Genetic analysis of inflammatory bowel disease in a large European cohort supports linkage to chromosomes 12 and 16. Gastroenterology 1998;115:1066-71.

14 Hampe J, Hermann B, Bridger S, Macpherson AJ, Mathew CG, Schreiber S. The interferon-gamma gene as a positional and functional candidate gene for inflammatory bowel disease. Int J Colorectal Dis 1998;13:260-3.

15 Hampe J, Schreiber S, Shaw SH, Lau KF, Bridger S, Macpherson AJ, Cardon LR, Sakul H, Harris TJ, Buckler A, Hall J, Stokkers P, van Deventer SJ, Nurnberg P, Mirza MM, Lee JC, Lennard-Jones JE, Mathew CG, Curran ME. A genomewide analysis provides evidence for novel linkages in inflammatory bowel disease in a large European cohort. Am J Hum Genet 1999:64:808-16.

16 Olavesen MG, Hampe J, Mirza MM, Saiz R, Lewis CM, Bridger S, Teare D, Easton DF, Herrmann T, Scott G, Hirst J, Sanderson J, Hodgson SV, Lee J, MacPherson A, Schreiber S, Lennard-Jones JE, Curran ME, Mathew CG. Analysis of single-nucleotide polymorphisms in the interleukin-4 receptor gene for association with inflammatory bowel disease. Immunogenetics 2000;51:1-7

17 Lennard-Jones JE. Classification of inflammatory bowel disease. Scand J Gastroenterol Suppl 1989;170:2-6.

18 Truelove SC, Pena AS. Course and prognosis of Crohn's disease. Gut 1976;17:192-201

19 Hampe J, Wollstein A, Lu T, Frevel HJ, Will M, Manaster C, Schreiber S. An integrated system for high throughput TaqMan based SNP genotyping. Bioinformatics 2001;17:654-5.

20 Clayton D. A generalization of the transmission/disequilibrium test for uncertain-haplotype transmission. Am J Hum Genet 1999;65:1170-7.

21 Clayton D, Jones H. Transmission/disequilibrium tests for extended marker haplotypes. Am J Hum Genet 1999;65:1161-9.

22 Humphries SE, Martin S, Cooper J, Miller G. Interaction between smoking and the stromelysin-1 (MMP3) gene 5A/6A promoter polymorphism and risk of coronary heart disease in healthy men. Ann Hum Genet 2002;66:343-52.

23 Liu PY, Chen JH, Li YH, Wu HL, Shi GY. Synergistic effect of stromelysin-1 (matrix metallo-proteinase-3) promoter $5 \mathrm{~A} / 6 \mathrm{~A}$ polymorphism with smoking on the onset of young acute myocardial infarction. Thromb Haemost 2003:90:132-9.

24 de Maat MP, Jukema JW, Ye S, Zwinderman AH, Moghaddam PH, Beekman M, Kastelein JJ, van Boven AJ, Bruschke AV, Humphries SE, Kluft C, Henney AM. Effect of the stromelysin-1 promoter on efficacy of pravastatin in coronary atherosclerosis and restenosis. Am J Cardiol 1999;83:852-6.

25 Medley TL, Kingwell BA, Gatzka CD, Pillay P, Cole TJ. Matrix metalloproteinase-3 genotype contributes to age-related aortic stiffening through modulation of gene and protein expression. Circ Res 2003;92:1254-61.

26 Humphries SE, Luong LA, Talmud PJ, Frick MH, Kesaniemi YA, Pasternack A, Taskinen MR, Syvanne M. The 5A/6A polymorphism in the promoter of the stromelysin-1 (MMP-3) gene predicts progression of angiographically determined coronary artery disease in men in the LOCAT gemfibrozil study. Lopid Coronary Angiography Trial. Atherosclerosis 1998; 139:49-56.

27 Terashima M, Akita H, Kanazawa K, Inoue N, Yamada S, Ito K, Matsuda Y, Takai E, Iwai C, Kurogane H, Yoshida Y, Yokoyama M. Stromelysin promoter $5 \mathrm{~A} / 6 \mathrm{~A}$ polymorphism is associated with acute myocardial infarction. Circulation 1999;99:2717-19.

28 Beyzade S, Zhang S, Wong YK, Day IN, Eriksson P, Ye S. Influences of matrix metalloproteinase-3 gene variation on extent of coronary atherosclerosis and risk of myocardial infarction. J Am Coll Cardiol 2003;41:2130-7.

29 Satsangi J, Chapman RW, Haldar N, Donaldson P, Mitchell S, Simmons J, Norris S, Marshall SE, Bell Jl, Jewell DP, Welsh KI. A functional polymorphism of the stromelysin gene (MMP-3) influences susceptibility to primary sclerosing cholangitis. Gastroenterology 2001;121:124-30.

30 Constantin A, Lauwers-Cances V, Navaux F, Abbal M, van Meerwijk J, Mazieres B, Cambon-Thomsen A, Cantagrel A. Stromelysin 1 (matrix metalloproteinase 3) and HLA-DRB1 gene polymorphisms: association with severity and progression of rheumatoid arthritis in a prospective study. Arthritis Rheum 2002;46:1754-62. 